\title{
A CONCEPTUAL STUDY ON DHOOPANA KARMA IN KAPHAJA YONI VYAPADW.S.R TO VULVO-VAGINAL CANDIDIASIS
}

\author{
Dr.Kiran. $\mathbf{A}^{\mathbf{1}}$ \\ ${ }^{l}$ PG Scholar, Department of Prasuthi Tantra and Stree Roga, Shri Dharmasthala Manjunateshwara college of \\ Ayurveda and Hospital, Hassan
}

Dr.Madhu.M ${ }^{2}$

${ }^{2}$ Associate professor, Department of Prasuthi Tantra and Stree Roga, Shri Dharmasthala Manjunateshwara college of Ayurveda and Hospital, Hassan

DOI: https://doi.org/10.36713/epra3859

\begin{abstract}
Ayurveda Prasuti Tantra and Stree Roga is a specialised branch of science contributed purely for women ailments and their management, including pregnancy. Women face a number of illnesses related to the reproductive organ, mainly during the fertile age. Problems related to the genital tract and organs are broadly explained under Yoni Vyapads in Stree Roga. The concept of Yoni Vyapad is briefed vastly in all Bruhatrayis. There are 20 Yoni Vyapad explained based on the involvement of doshas viz; Vataja, Pittaja, Kaphaja, Dwandwaja and Sannipataja, Krimi and Rakthaja; out of which Kaphaja Yoni Vyapad is one, explained by all Acharyas and is co-related to Vulvo-vaginal Candiasis. It is a condition that exhibits symptoms of vaginal white discharge which is thick and curdy and associates with vulval itching. Yoni vyapads carry most distinct treatment modalities called Stanika Chikitsa which includes yoni prakshalana, Yoni Picuh, Yoni Varti, Yoni Dhoopana, Yoni Abhyanga etc, wherein local therapies confined to the affected site, is done. Dhoopana karma is a boon in such conditions as it has Krimighna, Vrana ropana, Sroto Shodana and Sravaghna properties. Yoni Dhoopana is one of the Stanika chikitsa where fumigation of the Yoni pradesha is performed in various indicated conditions by using suitable drugs. Here an effort is made to compile the drugs and their properties in Dhoopana karma and its favour in the condition of Kaphaja Yoni Vyapad (Vulvo-Vaginal candidiasis)

KEY WORDS: Ayurveda, Kaphaja Yoni Vyapad, Vulvo-Vaginal Candidiasis, Yoni Dhoopana Karma.
\end{abstract}

ABSTRACT

\section{INTRODUCTION}

Yoni Vyapad are of major ailment sector confined to Female Reproductive Organ. The common causes explained for any conditions of such are, Mithyahara Vihara, Artava Dusti, Shukra Dushti, Daiva. Kaphaja Yoni Vyapad is one among the ailments explained under Sleshmaja Yoni Vyapad. The main cause of Kaphaja Yoni Vyapad explained to be Mithya Ahara viz, Ati Snighda and Abhishyandi ahara that does dushana to the Yoni
Pradesha causing excess Sweta Srava which is Snighda, Pandu Varna, Picchila associated with Kandu․ Acharya Sushruta has explained the characteristics of Kaphaja Yoni Vyapad being, Atisheeta srava which is Pandu Varna and is associated with Kandu ${ }^{2}$. The main line of treatment explained for Kaphaja Yoni Vyapad is Yoni Varti Dharana, Yoni Prakshalana as a part of Stanika chikitsa. Dhoopana karma can also be practised as a line of Stanika Chikitsa for this condition as there is involvement of dushita kapha and Kandu being one 
of the main symptoms that is manifested. Acharya Kashyapa has contributed a separate chapter on Dhoopana karma in various contexts which also includes Rakshoghna Karma and krimghna karma ${ }^{3}$ . Since the recurrence is high, it is important to maintain a healthy genital environment. Hence considering the properties of Dhoopana, this mode of treatment can help producing satisfactory results in Kaphaja Yoni Vyapad.

\section{MATERIAL AND METHOD}

For the study, references are obtained from the primary source of literature ie; classics of Ayurveda, modern litrature and articles, journals, previous studies from different centres of research and studies.

\section{WHAT IS KAPHAJA YONI VYAPAD?}

Kapaja Yoni Vyapad is one among 20 vyapads, explained under Kapha doshaja vyapad ${ }^{4}$. A Kapha pradhana along with the influence of Vata,that affects the Yoni. The most common symptoms seen in this condition as explained by Acharya's are Yoni Kandu, Alpa Vedana, Yoni Srava which is Ghana, Picchila and Sheeta ${ }^{1}$,a classical discharge which is curdy or thick white , associated with severe itching that may or may not accompany with mild pain in the genitals. However, Vagbhattacharya explains additional symptom as yellowish discharge per vagina with or without mild pain $^{5}$. The causative factor includes Ahara or Vihara that increase Kapha dosha and also Vata without which any Yoni Vyapadis a far possibility. The main causative factors in this condition is intake of Abhishyandi Ahara ${ }^{6}$.The treatment approach toward this condition mainly focuses on detecting the Nidana, correcting the Kapha- Vata dusti and also maintaining the healthy state of the Yoni. The proposed line of treatment for any Yoni Vyapad includes both Shodhana and Shamana karma and a special therapeutic modality called Sthanika Chikitsa. The symptoms of this condition exhibits local vitiation of the Dosha and hence Stanika Chikthsa is done as a special treatment approach. The Stanika Chikitsa explained for Kaphaja Yoni Vyapad include Yoni Varti Dharana, Yoni Kalka Dharana and Shodhana highlights over Basti Karma ${ }^{7}$ .On the bases of the exhibited symptoms of Kaphaja Yoni Vyapad Rookshana, Ushan Pradhana treatment is required to regress the condition. As per the description of Acharya Charaka-

"Sleshmajaasu cha rookshoshnam karma kuryadhvichkshanaha ${ }^{8}$
Hence on considering the concept of Rookshana and Ushan therapies, other treatments that can be applied apart from yoni prakshalana, yoni pichu dharana and Dhoopana. As the condition possess kapha pradhana symptoms, one of the ideal stanika chikitsa is yoni Dhoopana karma

\section{VULVO-VAGINAL CANDIDIASIS}

Candida albicans is one of the most common among all the types of Candidia infections. Yeast infection to the genital organs is the condition seen in women of reproductive age group. They exhibit symptom such as thick white or curdy white discharge like flakes or appears to be like cottage cheese. It is associated with severe itching and redness with or without rashes are seen in a local vaginal examination. The discharge may also be yellowish in colour with or without foul smell. It is diagnosed by taking a swab of vaginal discharge and on viewing under microscope, there is presence of pseudo hyphae and budding yeast cells typical of candida species. In culture method, the swab taken from the vagina is smeared over the culture media. The media is kept undisturbed for several days to allow the yeast to form colonies, if there is presence of the species. It is a treatable condition, but recurrence is common.

\section{DHOOPANA KARMA}

Dhoopana is a measure to maintain the healthy external and internal environment of the human and surroundings. It has a broad specialized effect in spiritual, medicinal and psychological aspects. Dhoopana karma implies to fumigation of the desired or the affected area, with essential drugs or objects required as per need. Generally the drugs chosen for Dhoopana mainly throw light on the Guna and Karma of Dravya depending on the condition where they are used, and also the rapid volatility and spread ability of the properties of the drug. As therapeutics, it plays an important role in the conditions where there is vedana, infestation of Krumi, Ati Srava, Kandu, Vrana as-in diseased condition and also to sterilize the Chikitsagara, Sootikagra, Shastra, Yantra. The property of the Doopa in general are Rooksha, Laghu, Ushna, Vishada, hence can be used in conditions that produces opposite qualities . (Kshyapa samhita) 
Common drugs that can be used for Dhoopana in kaphaja Yoni Vyapadwith its properties

\begin{tabular}{|c|c|c|}
\hline Sl no & Drugs $^{9}$ & Properties \\
\hline 1 & Nimbaa $^{a}$ & $\begin{array}{l}\text { Tiktha , kashaya rasa } \\
\text { Laghu ruksha guna } \\
\text { Sheeta virya } \\
\text { Katu vipaka }\end{array}$ \\
\hline 2 & Jatamansib & $\begin{array}{l}\text { Tiktha kashaya madhura rasa } \\
\text { Laghu snighdha guna } \\
\text { Sheeta virya } \\
\text { Katu vipaka }\end{array}$ \\
\hline 3 & Gugguluc & $\begin{array}{l}\text { Thikta kashay a rasa } \\
\text { Laghu guna } \\
\text { Sheeta virya } \\
\text { Katu vipaka }\end{array}$ \\
\hline 4 & Haridrad $^{d}$ & $\begin{array}{l}\text { Tiktha katu rasa } \\
\text { Ushna veerya } \\
\text { Katu vipaka } \\
\text { Laghu rooksgha guna }\end{array}$ \\
\hline 5 & Agarue & $\begin{array}{l}\text { Katu tiktha rasa } \\
\text { Laghu tikshna guna } \\
\text { Ushna virya } \\
\text { Katu vipaka }\end{array}$ \\
\hline 6 & Vacha $^{f}$ & $\begin{array}{l}\text { Katu thiktha rasa } \\
\text { Laghu tikshna guna } \\
\text { Ushna virya } \\
\text { Katu vipaka }\end{array}$ \\
\hline 7 & Hingug & $\begin{array}{l}\text { Katu rasa } \\
\text { Laghu snighdha tikshna guna } \\
\text { Ushna virya } \\
\text { Katu vipaka }\end{array}$ \\
\hline 8 & Sarjarasa $^{\text {h }}$ & $\begin{array}{l}\text { Kashaya madhura rasa } \\
\text { Rooksha ushna guna } \\
\text { Sheeta virya } \\
\text { Katu vipaka }\end{array}$ \\
\hline 9 & Sarshapai & $\begin{array}{l}\text { Katu tiktha rasa } \\
\text { Laghu snighdha guna } \\
\text { Ushna virya } \\
\text { Katu vipaka }\end{array}$ \\
\hline 10 & Lavana 10 & $\begin{array}{l}\text { Lavana, madhura rasa } \\
\text { Laghu rooksha guna } \\
\text { Sheeta virya } \\
\text { Madhura vipaka }\end{array}$ \\
\hline 11 & Pippalij & $\begin{array}{l}\text { Katu rasa } \\
\text { Laghu tikshna guuna } \\
\text { Ushna virya } \\
\text { Madhura vipaka }\end{array}$ \\
\hline 12 & Tulasik & $\begin{array}{l}\text { Katu tiktha rasa } \\
\text { Laghu rooksha tikshna guna } \\
\text { Ushna virya } \\
\text { Katu vipaka }\end{array}$ \\
\hline 13 & Brihatipahalal $^{1}$ & $\begin{array}{l}\text { Katu tiktha rasa } \\
\text { Laghu rooksha guna } \\
\text { Ushna virya } \\
\text { Katu vipaka }\end{array}$ \\
\hline 14 & Kustam $^{m}$ & $\begin{array}{l}\text { Tiktha rasa } \\
\text { Laghu rooksha teekshna guna } \\
\text { Ushna virya } \\
\text { Katu vipaka }\end{array}$ \\
\hline 15 & Khadiran $^{n}$ & $\begin{array}{l}\text { Tiktha kashaya rasa } \\
\text { Laghu rooksha guna } \\
\text { Sheeta virya } \\
\text { Katu vipaka }\end{array}$ \\
\hline
\end{tabular}




\section{PROCEDURE}

The classical Dhoopana procedure comprises of the following steps:

- The patient is told to evacuate the bladder.

- The pot which contained pre-heated coal till red hot is kept ready

- A procedure of Yoni Prakshalana can be done before Dhoopana as pre-procedure.

- The desired drugs in Churna form are added over it so as to produce dense fumes and kept under the chair with vent in the middle

- The fumes reaches the external genitalia, passing through the vent

- This is done till a desired time (5-10 min on an average )

\section{DISCUSSION}

Kaphaja Yoni Vyapad, which can be correlated to Vulvo-Vaginal Candidiasis, is one of the commonest problems faced by women in her reproductive life. It is a manageable condition and Stanika Chikitsa plays an important role as a line of treatment in such condition. Dhoopana Karma is chosen as it has properties of Sroto Shodhana, Ushna, Rooksha Guna which in turn reduced the symptoms. It poses properties opposite to those of Kapha Gunas and hence is an ideal procedure. As it also has Krimighna property, it can be planed as a localised treatment. As also, there is minimal intervention in the procedure, with such efficacy, it can be taken forward in treatment protocol in Kaphaja Yoni Vyapad, and other such Krimi condition.

\section{CONCLUSION}

Kaphaja Yoni Vyapadis a condition that can be managed by proper hygiene and deitic habits. An additional suppository management through Ayurveda yields satisfactory results in this condition. Stanika Chikitsa, however is a boon in such case, helps in mainitating a healthy localised environment preventing it from any further infections.

\section{REFERENCES}

1. R.K. Sharma And Bhagwan Dash, charaka samhitha, chakrapani dhatta, Ayurveda deepika Varanasi chawkambha sanskri series office, 2013, chikitsa stana 30/13-14, page no : 132

2. Keval Krishna takraal, sushrutha samhitha, dalhana , nibanda sanghraha, Varanasi chawkambha orientalia, 2015, uttara stana 38/28

3. Hemaraja sharma, kashyapa samhitha, vriddha jeevaka , Varanasi chawkambha sanskritha samsthan, 2018, kalpa stana, pg no: 246

4. R.K. Sharma And Bhagwan Dash, charaka samhitha, chakrapani dhatta , Ayurveda deepika Varanasi chawkambha sanskri series office, 2013, chikitsa stana 30/7, page no: 130

5. C. Dwarakanath, astanga sangraha, Varanasi chawkambha series, 2010, uttara sthana 38/55.

6. R.K. Sharma And Bhagwan Dash, charaka samhitha, chakrapani dhatta , Ayurveda deepika Varanasi chawkambha sanskri series office, 2013, chikitsa stana 30/13, page no : 132
7. R.K. Sharma And Bhagwan Dash, charaka samhitha, chakrapani dhatta, Ayurveda deepika Varanasi chawkambha sanskri series office, 2013 , chikitsa stana 30/70-73, page no: 148

8. R.K. Sharma And Bhagwan Dash, charaka samhitha, chakrapani dhatta, Ayurveda deepika Varanasi chawkambha sanskri series office, 2013 , chikitsa stana 30/42, page no: 141

9. Dr. Prakash .L. Hegde and Dr. Harini A, textbook of Dravya Guna Vijnana, volume 2

$$
\begin{array}{ll}
\text { a. } & \text { pgno: } 605 \\
\text { b. } & \text { pgno: } 39 \\
\text { c. } & \text { pgno:319 } \\
\text { d. } & \text { pgno: } 333 \\
\text { e. } & \text { pgno: } 1 \\
f . & \text { pgno: } 850 \\
g . & p g n o: 371 \\
h . & \text { pgno: } 85 \\
\text { i. } & \text { pgno: } 776 \\
j . & \text { pgno: } 656 \\
\text { k. } & \text { pgno: } 837 \\
\text { l. } & \text { pgno: } 204 \\
\text { m. } & \text { pgno: } 525 \\
\text { n. } & \text { pgno: } 487
\end{array}
$$

10. Vaidhya Tadavji Trikamji Acharya, Charaka samhitha, chakrapani dhatta , Ayurveda deepika Varanasi chawkambha Orientalia , 2013 , Sutra stana 26/42, page no:150 